\title{
The anaerobic corrosion of carbon steel in alkaline media - Phase 2 results
}

\author{
N.R. Smart ${ }^{1, \mathrm{a}}$, A.P. Rance ${ }^{1}$, P.A.H. Fennell ${ }^{1}$ and B. Kursten ${ }^{2}$ \\ ${ }^{1}$ AMEC, Building 150, Harwell Oxford, Didcot, Oxfordshire OX11 0QB, United Kingdom \\ ${ }^{2}$ SCK-CEN, Boeretang 200, B-2400 Mol, Belgium
}

\begin{abstract}
In the Belgian Supercontainer concept a carbon steel overpack will surround high-level waste and spent fuel containers and be encased in a cementitious buffer material. A programme of research was carried out to investigate and measure the rate of anaerobic corrosion of carbon steel in an artificial alkaline porewater that simulates the aqueous phase in the cementitious buffer material. The corrosion rates were measured by monitoring hydrogen evolution using a manometric gas cell technique and by applying electrochemical methods. Phase 2 of the programme has repeated and extended previous Phase 1 measurements of the effects of radiation, temperature and chloride concentration of the anaerobic corrosion rate. This paper provides an update on the results from Phase 2 of the programme. The results confirm previous conclusions that the long-term corrosion rate of carbon steel in alkaline simulated porewater is determined by the formation of a thin barrier layer and a thicker outer layer composed of magnetite. Anaerobic corrosion of steel in cement requires an external supply of water.
\end{abstract}

\section{Introduction}

The reference design for the Belgium Supercontainer for disposal of high-level nuclear waste and spent fuel consists of a $30 \mathrm{~mm}$ thick carbon steel cylindrical vessel ('the overpack') surrounding 309 grade stainless steel waste canisters. The overpack will be surrounded by a cementitious buffer material, which may or may not be encased in a stainless steel vessel ('the envelope'). This paper is concerned with the anaerobic corrosion processes that may affect the carbon steel overpack within the Supercontainer. The carbon steel will be exposed to alkaline porewater in the cementitious buffer or in the alkaline material that may be used as a filler in the annulus between the cementitious buffer and the overpack. After a relatively short period the interface between the steel and the alkaline porewater will become anoxic as residual oxygen in the repository is consumed by aerobic corrosion and microbial activity. Low concentrations of chloride (typically $100 \mathrm{mgl}^{-1}$ ) from the groundwater may penetrate the buffer and reach the surface of the overpack. There is a possibility that sulphurcontaining species could also be present at the interface between the canister and the cementitious buffer material [1]. In the proposed Belgian repository the sulphur near the waste containers will be present as sulphide, in the form of the mineral pyrite, $\mathrm{FeS}_{2}$ and sulphate as a dissolved species in the Boom Clay groundwater, at a maximum concentration of up to $6 \mathrm{mg} / \mathrm{l}$. However, disturbing the Boom clay leads to the formation of higher concentrations of sulphate, through the oxidation of

\footnotetext{
a e-mail: nick.smart@amec.com
} 
pyrite, which is present at concentrations of $\sim 5 \mathrm{wt} \%$ in the Boom clay. This may lead to sulphate concentrations as high as $20 \mathrm{gl}^{-1}$, together with $720 \mathrm{mgl}^{-1}$ thiosulphate.

An experimental programme is being conducted to investigate (i) the possible effect of gamma radiation on the anaerobic corrosion rate of carbon steel in cementitious porewaters and on the nature of the corrosion products formed, and (ii) the effect of radiation on the electrochemical and corrosion behaviour of carbon steel corroding anaerobically in simulated concrete porewater conditions, including the effects of sulphur species. Previous publications have described the experimental arrangements and reported earlier results from this programme [2-4] for both gas generation and electrochemical measurements; this programme follows from previous work in the field [5-8]. The aim of the present paper is to present some recent results from Phase 2 of the programme. The anaerobic corrosion of iron releases hydrogen by the following overall reaction:

or, if the Schikorr reaction [9] occurs, by the reaction:

$$
\mathrm{Fe}+2 \mathrm{H}_{2} \mathrm{O} \rightarrow \mathrm{Fe}(\mathrm{OH})_{2}+\mathrm{H}_{2} \uparrow
$$

$$
3 \mathrm{Fe}+4 \mathrm{H}_{2} \mathrm{O} \rightarrow \mathrm{Fe}_{3} \mathrm{O}_{4}+4 \mathrm{H}_{2} \uparrow
$$

Consequently, it is possible to monitor the progress of the iron anaerobic corrosion reaction by measuring the rate of hydrogen production. In the presence of sulphide the formation of iron sulphides, such as $\mathrm{FeS}$ or $\mathrm{FeS}_{2}$, becomes a possibility, together with a range of non-stoichiometric iron sulphides [1]. There are a various naturally occurring sulphide minerals with a range of crystal structures [1]. The effect of sulphide films on the anaerobic corrosion rate of iron in alkaline conditions and the consequent rate of generation of hydrogen has not been established experimentally and this issue is being addressed in the current programme; however this phase of the programme is at a preliminary stage and the results will be reported in a future paper.

\section{Experimental}

The experimental programme consisted of two parallel sets of measurements, firstly to monitor the rate of gas generation due to the anaerobic corrosion of carbon steel in alkaline conditions and secondly to monitor the electrochemical behaviour of carbon steel in simulated cementitious conditions, under both unirradiated and irradiated conditions. Gas generation rates and hence corrosion rates were measured using glass gas cells. The gas cell measurements were performed in two phases; in Phase 2, a modified design of gas cell was employed to make them more robust under irradiated conditions and to make them less susceptible to unplanned power interruptions. In Phase 2 the measurements from Phase 1 were repeated. Similarly, electrochemical measurements were carried out in two phases. The results from Phase 1 are described in references [2] to [4]. In Phase 2 electrochemical behaviour was studied using sealed glass cells, for the irradiated experiments, or sealed stainless steel autoclaves with electrical feedthroughs for the unirradiated experiments.

\subsection{Dose rate and temperature}

In the Supercontainer concept the dose rates of interest are $0.6 \mathrm{~Gy} \mathrm{hr}^{-1}$ (the average dose in the cement buffer) and 23-25 Gy hr-1 (the dose rate at the surface of the overpack). However, to reduce the matrix of experiments to a manageable size, experiments were conducted at 0 and 23-25 Gy hr ${ }^{-1}$ only. The required $\gamma$-radiation dose rate was achieved by locating the experiments at appropriate distances from a cobalt-60 source (average energy $1.25 \mathrm{MeV}$ ) in a gamma irradiation facility at Harwell, Oxfordshire, UK. Additional shielding was used where necessary to give the required dose rate. It was also necessary to carry out gas cell experiments and electrochemical measurements in the absence of radiation, to provide control data for comparison with the irradiated experiments. The experiments were carried out at temperatures of $25^{\circ} \mathrm{C}$ and $80^{\circ} \mathrm{C}$. This range of temperatures was chosen to provide data over a range of possible operational conditions and periods after closure of the Belgian repository. 


\subsection{Materials}

The carbon steel proposed for use in the Supercontainer is P-235GH (EN 10028-2 steel number 1.0345; BS1501-1:1980) but the nearest grade obtainable in wire form for the experiments described in this paper was Grade 1017, which has the composition (wt\%): C 0.17; Si 0.06; Mn 0.81; P 0.01; $\mathrm{S} \mathrm{0.03;} \mathrm{Cr} \mathrm{0.038.} \mathrm{This} \mathrm{steel} \mathrm{was} \mathrm{used} \mathrm{in} \mathrm{the} \mathrm{form} \mathrm{of} 0.4 \mathrm{~mm}$ diameter wire; wire was used in preference to coupons to provide a high surface area in the gas cell measurements. The total exposed surface area of the wire in the gas cells was $0.1 \mathrm{~m}^{2}$. All of the wires used in the current study were pickled under anoxic conditions in 10\% hydrochloric acid and thoroughly washed in demineralised water before use to minimise the amount of residual air-formed oxide. The same type of wire was used for electrodes in the electrochemical measurements.

The cementitious buffer proposed for use in the Belgian Supercontainer concept has the following composition $\left(\mathrm{kg} / \mathrm{m}^{3}\right)$ : CEM I $42.5 \mathrm{~N}-\mathrm{LA}-\mathrm{HSR}-\mathrm{LH}$ : 350; Calcitec $2001 \mathrm{MS}$ (ground calcium carbonate): 50; sand 0/4 (limestone): 708; calcareous aggregates (2/6): 414; calcareous aggregates (6/14): 191; calcareous aggregates (6/20): 465; w/c ratio 0.50; superplasticiser (Glenium, PC) : 4.4. The corrosion experiments were carried out in a simplified model porewater for this buffer material, corresponding to a relatively short period of time in the repository (known as 'Young cement porewater', YCW), with the following composition ( $\mathrm{mmol} \mathrm{l}^{-1} \mathrm{SO}_{4}{ }^{2-}$ 2.4; $\mathrm{OH}^{-} 510$; $\mathrm{K}^{+} 370$; $\mathrm{Na}^{+}$140; $\mathrm{pH} \sim 13.4$. Test solutions for the corrosion experiments were prepared under argon in a glovebox. Some experiments were carried out with the steel wire encapsulated in cement, while most experiments were carried out in aqueous conditions.

\subsection{Measurements of gas generation}

The rate of hydrogen production due to the anaerobic corrosion of steel wires in YCW with and without radiation was measured using a barometric gas cell technique [2]. The test pieces were placed in zirconia crucibles, which were used because of their resistance to chemical and radiochemical degradation in alkaline conditions. Any gas produced in the test cell caused a pressure increase, which resulted in the mercury rising up a glass manometer column. Details of the procedures for setting up and operating such cells have been described in previous publications (e.g. [2]). By measuring the height of the mercury it was possible to calculate the volume of gas produced and hence to derive the corrosion rate, based on Equation 2 (i.e. formation of magnetite was assumed). The results were corrected for temperature and external atmospheric pressure fluctuations. In order to allow for the possible release of gas due to radiolytic breakdown of the cell materials or radiolysis of the test solution, a control cell was set up for each test environment. The control cells were identical to the test cells, but did not contain any steel wires or in one case any steel or solution.

Carbon steel wire was cut into $79.58 \mathrm{~m}$ lengths (giving a total surface area of $0.1 \mathrm{~m}^{2}$ ), formed into a random coil that fitted into the crucible, then degreased in acetone. All subsequent cell preparation was conducted in an argon-purged glove box to ensure initial anoxic conditions in the cells. The wire was pickled in an ultrasonic bath containing $10 \% \mathrm{HCl}$ for 5 minutes, in order to remove the residual air-formed oxide, then rinsed in deionised water and dried before weighing. The control cells were used to monitor the amount of gas produced by radiolytic degradation of the construction materials and the water, and the values obtained were used to adjust the data obtained from the corrosion test cells. The matrix of gas cell experiments carried out in Phase 2 of the programme is shown in Table 1 (in white). All experiments were carried out in duplicate. In some experiments, wires that had been corroded in Phase 1 were transferred into fresh cells and monitoring of the corrosion rate continued.

Gas cells that contained cement paste samples were assembled in the same manner as the cells containing porewater solution, except that they used cement paste pucks within the zirconia crucibles. As for the cells containing porewater, $79.6 \mathrm{~m}$ of pickled wire was used, but in order for the wire to be uniformly encapsulated by the cement paste it was chopped into $5 \mathrm{~mm}$ lengths before cementation was carried out. Once chopped and pickled, the batches of wire were mixed into a cement paste within an argon-filled glove box. $100 \mathrm{ml}$ polypots were filled with liquid cement paste (with no aggregate present). For each Phase of the experimental programme, two polypots contained 
cement paste mixed with the chopped steel wires and two contained blank cement paste. Once poured the four samples were left to cure for $24 \mathrm{hrs}$. The following day the solid samples were removed from their respective pots and transferred into zirconia crucibles, which were placed into a glass gas cell. In Phase 1, four cells were set up with no water around the cement, but in Phase 2 the four cement samples were immersed in YCW.

Table 1. Matrix of gas cell experiments (white) and electrochemical measurements (grey) in 'Young cement water' carried out during Phase 2 of programme

\begin{tabular}{|c|c|c|c|c|}
\hline Tests in solution & $\begin{array}{c}{[\mathrm{Cl}]} \\
\left(\mathrm{mg} \mathrm{l}^{-1}\right)\end{array}$ & $\begin{array}{l}\text { Temp } \\
\left({ }^{\circ} \mathrm{C}\right)\end{array}$ & $\begin{array}{c}\gamma \text {-dose rate } \\
\left(G y h^{-1}\right)\end{array}$ & $\begin{array}{c}\text { Number } \\
\text { of tests }\end{array}$ \\
\hline Young Cement Water + steel & 0 & $25 \& 80$ & $0 \& 25$ & 8 \\
\hline Young Cement Water only (blank) & 0 & $25 \& 80$ & $0 \& 25$ & 8 \\
\hline Cells with no water or steel & 0 & 80 & 25 & 2 \\
\hline Young Cement Water + steel & 100 & 80 & $0 \& 25$ & 4 \\
\hline Young Cement Water only (blank) & 100 & 80 & $0 \& 25$ & 4 \\
\hline Cement + steel (no water, Phase 1) & 0 & 80 & 25 & 2 \\
\hline Cement only (blank, no water, Phase 1) & 0 & 80 & 25 & 2 \\
\hline Cement + steel (YCW around cement) & 0 & 80 & 25 & 2 \\
\hline Cement only (blank, YCW around cement) & 0 & 80 & 25 & 2 \\
\hline Young Cement Water + steel & 0 & $25 \& 80$ & $0 \& 25$ & 4 \\
\hline Young Cement Water + steel & 100 & 80 & $0 \& 25$ & 2 \\
\hline
\end{tabular}

\subsection{Electrochemical measurements}

In order to develop a fuller understanding of the electrochemical behaviour of anaerobically corroding steel, electrochemical measurements were made in representative environments (i.e. anoxic alkaline porewater simulant). The aim of these measurements was to compare the electrochemical behaviour of carbon steel in irradiated and un-irradiated, anoxic alkaline porewater conditions. In Phase 2 of the experimental programme, measurements in unirradiated conditions were made inside stainless steel autoclaves, which were used to provide a reliable gas tight environment for long-term measurements. Three autoclaves were prepared inside an argon-purged glovebox and the following electrodes were included:

- $\quad$ two anaerobically corroding steel test electrodes - approximately $0.4 \mathrm{~mm}$ diameter by $55 \mathrm{~mm}$ long, which were pickled in acid before immersion, under anoxic conditions;

- $\quad$ a gold electrode to measure Eh, redox potential;

- a platinum foil counter electrode, which was also used to monitor Eh;

- $\quad$ an oxidised tungsten wire pseudo-reference electrode;

- $\quad$ an iridium oxide pseudo-reference electrode.

The test solution was held in a PTFE crucible and the entire autoclave was placed in an oven for the experiments at $80^{\circ} \mathrm{C}$ or operated at ambient temperature $\left(13-31^{\circ} \mathrm{C}\right.$, average $\left.21.5^{\circ} \mathrm{C}\right)$. To avoid the use of glass reference electrodes for long-term measurements under highly alkaline conditions, the Phase 2 experiments used two pseudo-reference electrode systems, namely a tungsten-tungsten oxide pseudo-reference electrode and an iridium oxide pseudo-reference electrode. The potentials of the tungsten-tungsten oxide electrode potentials were calibrated in YCW under deoxygenated conditions, before and after the measurements. A value for the tungsten pseudo-reference electrode potential of $-500 \mathrm{mV}$ vs SHE in deaerated YCW was applied to obtain the potential values against the standard hydrogen electrode (SHE). The electrochemical cells were used to monitor the corrosion potential of the carbon steel electrodes, together with their corrosion rates based on linear polarisation resistance measurements and AC impedance measurements. The test conditions for the electrochemical test cells are shown in Table 1 in grey. 


\section{Results and discussion}

\subsection{Gas generation}

The results from the gas cell measurements made in Phase 2 of the programme, expressed as anaerobic corrosion rates (assuming magnetite as the corrosion product), are shown in Figure 1 and Figure 2 for unirradiated and irradiated conditions respectively. Both these plots show data corrected using the blank cells (i.e. the gas generation rates were corrected to allow for gas released due to thermal or radiation effects). The cells marked with $\mathrm{R}$ after the cell number correspond to cells that were repeats of the Phase 1 experiments and cells marked RH used corroded material that was taken from the Phase 1 cells and therefore had a pre-existing corrosion product layer on the surface when the experiments were restarted in Phase 2.

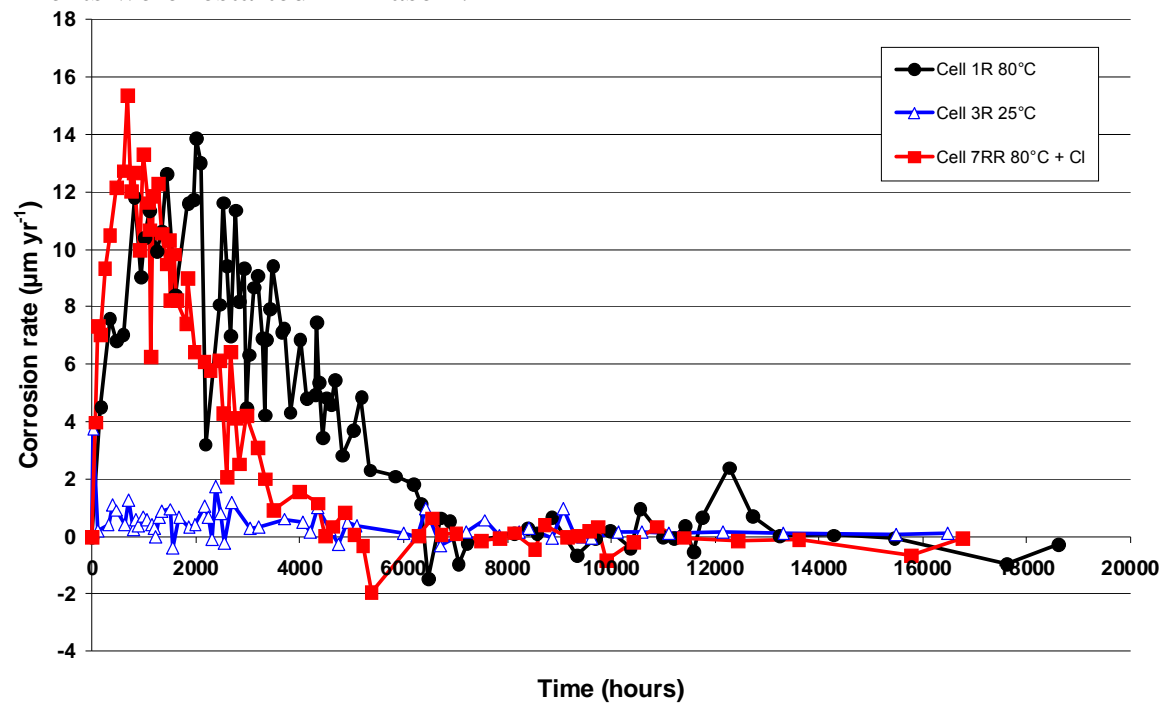

Fig. 1. Corrosion rate for carbon steel in Young Cement Water simulant, under unirradiated conditions, as a function of temperature and chloride concentration (adjusted against control cells), from Phase 2 experiments. The chloride concentration in Cell 7RR was 100 ppm.

The cumulative hydrogen production data for both unirradiated and irradiated cells are shown in Figure 3. The main features of the gas cell results are as follows:

1. For the unirradiated experiments (Figure 1) the peak corrosion rate on pickled surfaces was higher at $80^{\circ} \mathrm{C}$ compared to $25^{\circ} \mathrm{C}$. This is comparable to previous measurements [2-4] in similar conditions. The corrosion rates decreased with time; at both $25^{\circ} \mathrm{C}$ and $80^{\circ} \mathrm{C}$ the corrosion rate after 17,000 hours was approximately $0.1 \mu \mathrm{myr}^{-1}$. These values are also consistent with other published work on the anaerobic corrosion rate of iron and steel in alkaline conditions (e.g. [7, 10-16]).

2. For the irradiated experiments the initial corrosion rates on pickled material were higher than for unirradiated material. The steel wires that had been corroded previously under anaerobic conditions exhibited low corrosion rates when they were re-immersed in YCW (i.e. the cells marked RH in Figure 2). After 12,000 hours the corrosion rates of all the specimens was of the order of $0.1 \mu \mathrm{myr}^{-1}$ or less, but at these low corrosion rates the experimental variability for individual measurements was of the same magnitude. 


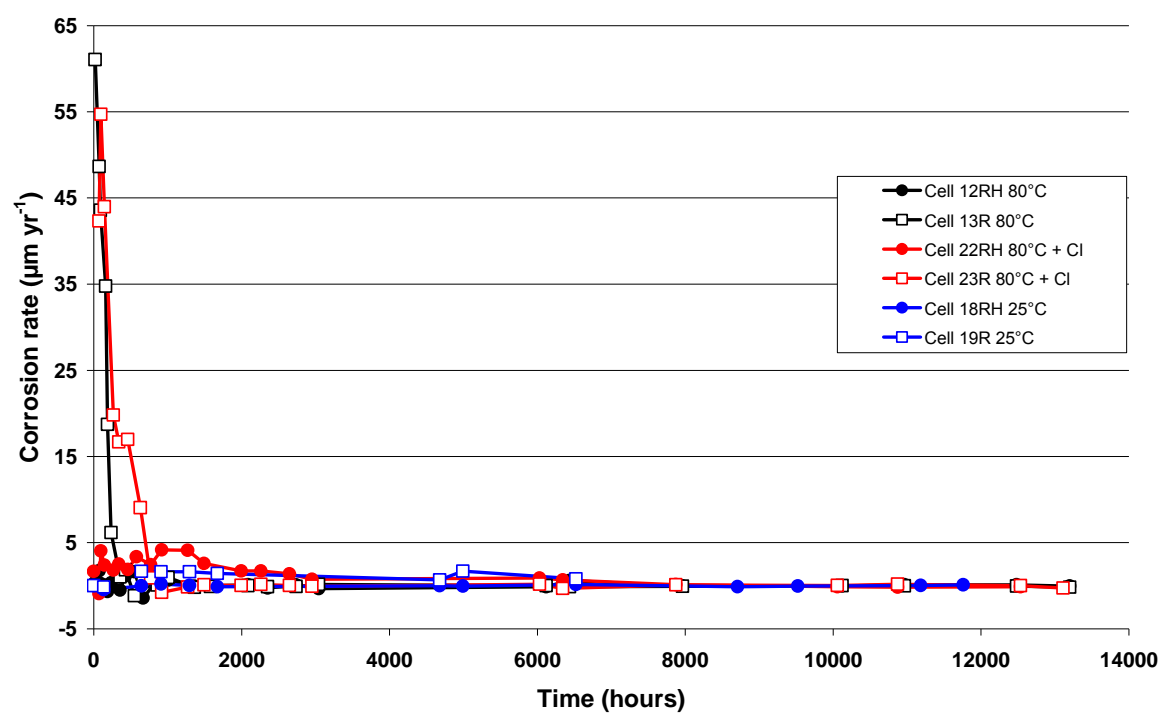

Fig. 2. Corrosion rate for carbon steel in YCW, under irradiated conditions $\left(25 \mathrm{~Gy} \mathrm{hr}^{-1}\right)$, as a function of temperature and chloride concentration (adjusted against control cells). $\mathrm{RH}=$ re-housed Phase 1 expt.; $\mathrm{R}=$ repeat of Phase 1 expt.

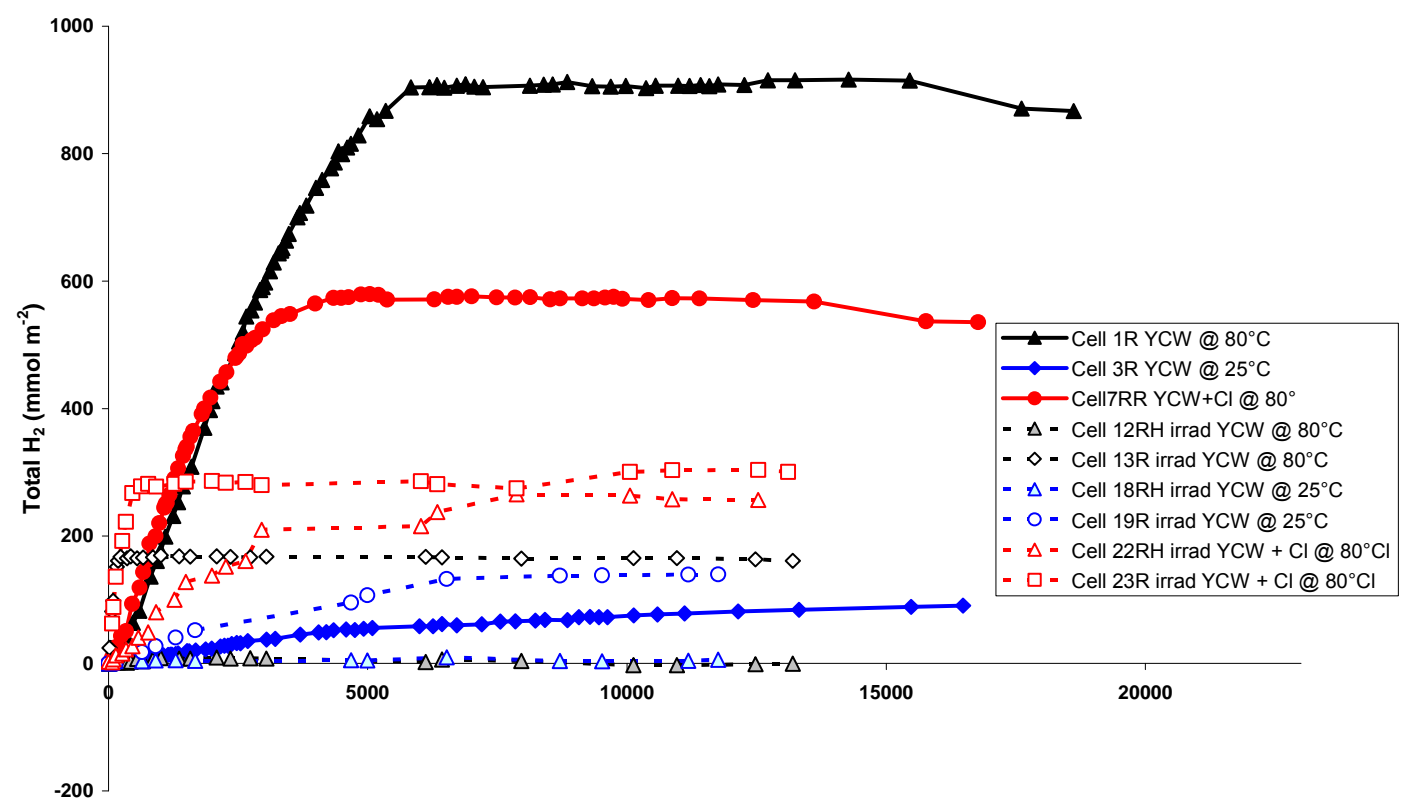

Time (hours)

Fig. 3. Cumulative hydrogen production due to anaerobic corrosion of carbon steel in YCW, under unirradiated and irradiated conditions ( $25 \mathrm{~Gy} \mathrm{hr}^{-1}$ ), as function of temperature and chloride concentration (adjusted vs control). $\mathrm{RH}=$ re-housed Phase 1 expt.; $\mathrm{R}=$ repeat of Phase 1 expt.

3. Figure 3 shows that within the normal statistical experimental variation, radiation at $25 \mathrm{Gyhr}^{-1}$ did not increase the rate of hydrogen production, in fact it appears to reduce the long-term corrosion rate compared to unirradiated specimens. This may be because radiation appears to shift the corrosion potential to more negative values [4]. 
4. Experiments in cement showed that hydrogen is generated by anaerobic corrosion of steel in cement when the cement is immersed in water (Figure 4). Previous experiments in cement that was not in contact with YCW did not generate any gas [3]. This suggests that the corrosion rate for steel in cement is limited by the water supply.

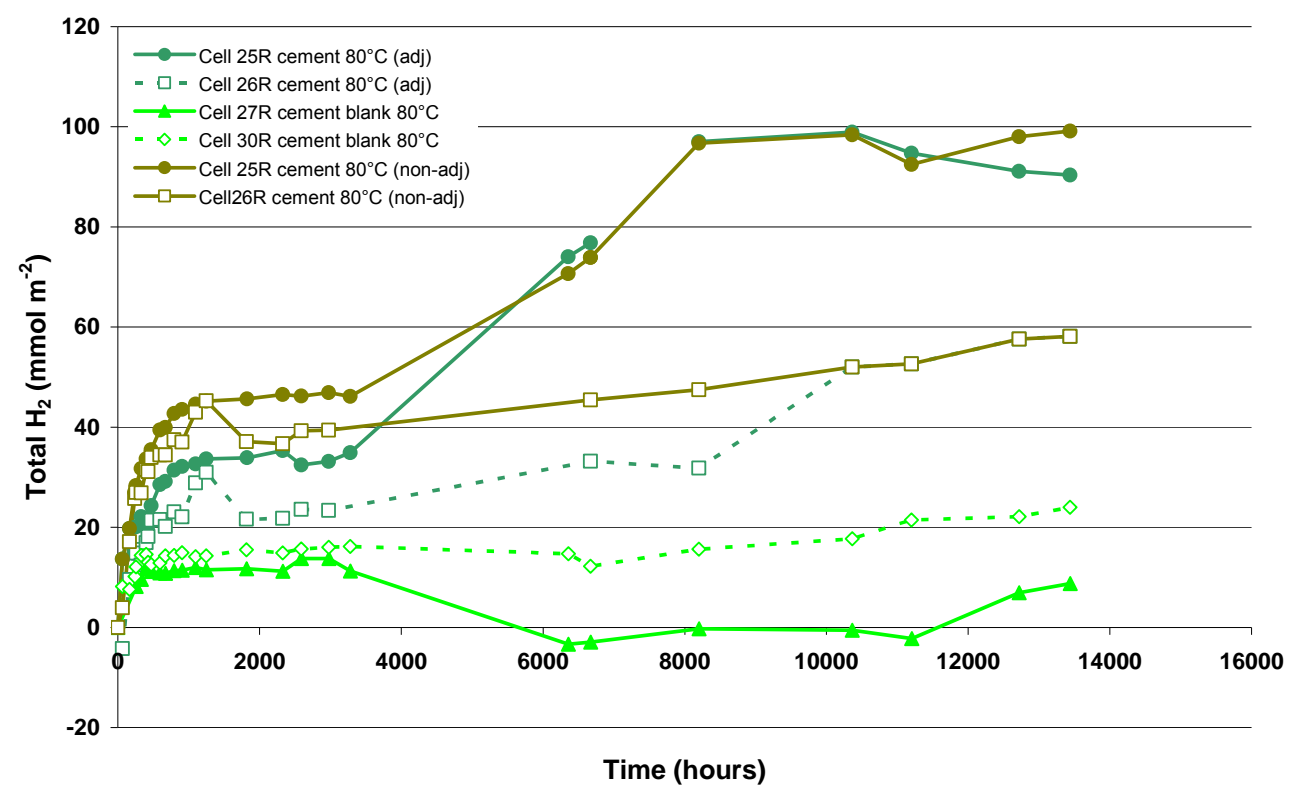

Fig. 4. Cumulative hydrogen production due to anaerobic corrosion of carbon steel in cement, under irradiated conditions (25 Gy hr ${ }^{-1}$ ) at $80^{\circ} \mathrm{C}$, showing results for blank cells, and adjusted and unadjusted results.

\subsection{Electrochemical measurements}

Examples of the potentials measured in the autoclaves containing the anaerobically corroding carbon steel electrodes are shown in Figure 5. When the cells were dismantled the carbon steel electrodes were observed to be black and there was a small amount of black particulate material suspended in a pale yellow-green solution. This colouration is consistent with the presence of dissolved ferrous ions. When the black solid was dried it was found to react to a magnet, indicating the presence of magnetite, which is in agreement with previous Raman analysis of the surface of anaerobically corroded steel [3]. The long-term potentials of the steel electrodes were generally in the region of the magnetite domain of stability in the Pourbaix diagram for iron, although there were considerable long-term fluctuations in the potentials. The reasons for these fluctuations are not clear but are presumed to be due to local time-dependent variations in solution chemistry near the electrode surfaces.

The observation of a low corrosion rate in the gas cell measurements, which decreases with time, is consistent with the rapid formation of a thin barrier layer on the surface of the steel, with the slow subsequent development of an outer layer through a dissolution-precipitation process [17].

\section{Conclusions}

The main conclusions from Phase 2 of this work programme are as follows:

1. The gas generation rate experiments show high initial corrosion rates on pickled surfaces, with the initial corrosion rate higher at $80^{\circ} \mathrm{C}$ than at $25^{\circ} \mathrm{C}$. The corrosion rate falls more rapidly at $80^{\circ} \mathrm{C}$ than at $25^{\circ} \mathrm{C}$. The results are similar to those produced in Phase 1 of the programme, but there was statistical scatter between experiments; the results of repeat tests were not identical. 
2. The long-term anaerobic corrosion rate is $<0.1 \mu \mathrm{m} \mathrm{yr}^{-1}$ and slowly decreases. The results are consistent with the formation of an inner barrier layer and outer layer of magnetite. Irradiation at 23-25 Gy hr ${ }^{-1}$ did not increase the gas generation rate.

3. Hydrogen generation was detected from anaerobic corrosion of steel embedded in cement when it was immersed in water, but the absolute rates were lower than in purely aqueous environments. No gas generation was observed for steel embedded in cement that was not immersed in water.

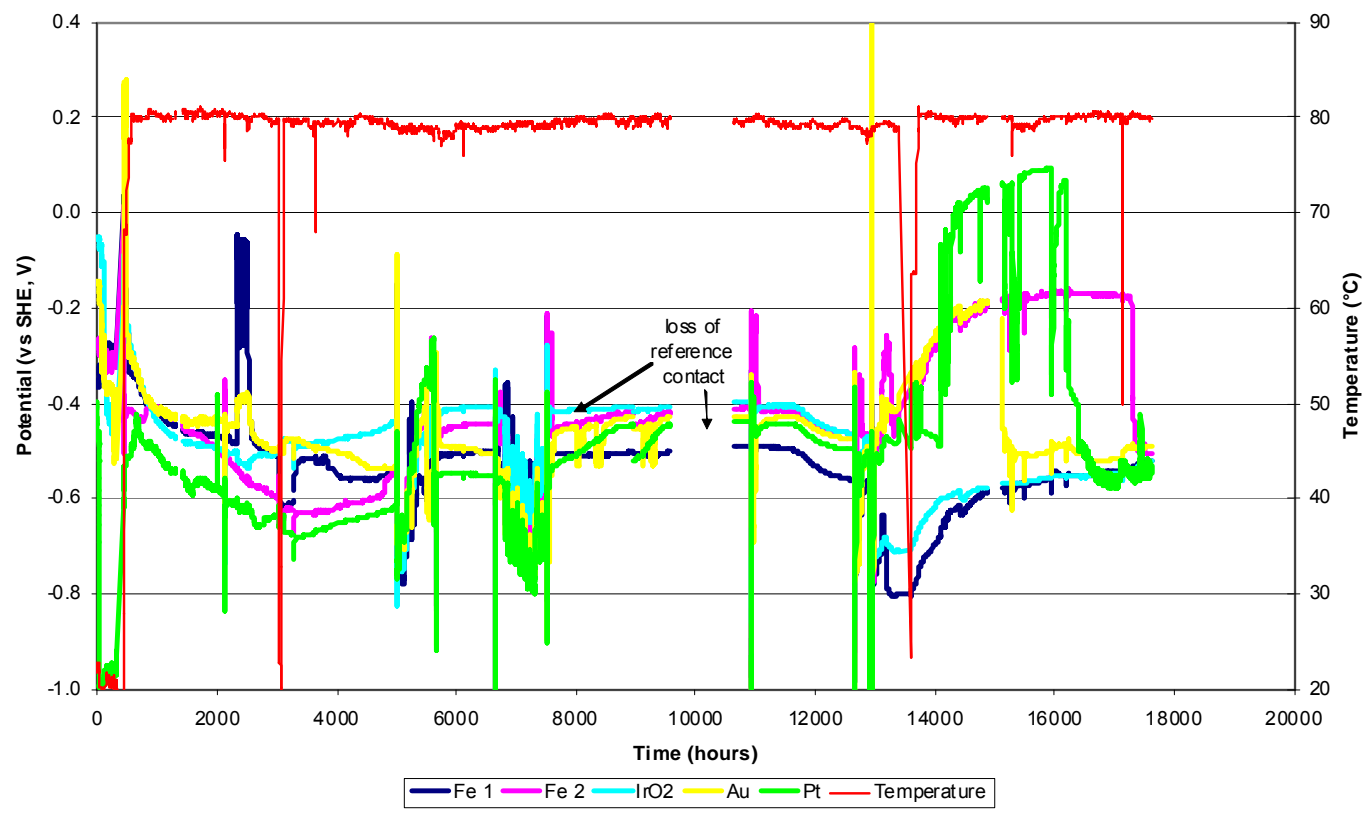

Fig. 5. Electrode potentials for unirradiated autoclave electrochemistry cell with anoxic YCW at $80^{\circ} \mathrm{C}$.

\section{References}

1 N.R. Smart, The Anaerobic Corrosion of Carbon Steel and the Potential Influence of Sulphur Species, Chapter 5 in European Federation of Corrosion publication EFC 59: Sulphur-Assisted Corrosion in Nuclear Disposal Systems, 81, (2011)

2 N.R. Smart, A.P. Rance, R.J. Winsley, P.A.H. Fennell, B. Reddy, B. Kursten, NUCPERF 2009 conference on Long-Term Performance of Cementitious Barriers and Reinforced Concrete in Nuclear Power Plants and Waste Management, RILEM proceedings PRO 64, 45, (2009)

3 R.J. Winsley, N.R. Smart, A.P. Rance, P.A.H. Fennell, B. Reddy, B. Kursten, Corrosion Engineering, Science and Technology 46, 111-116 (2011)

4 N.R. Smart, P.A.H. Fennell, A.P. Rance, R.J. Winsley, B. Reddy, B. Kursten, The European Physical Journal (EPJ) Web of Conferences 12, Paper 02003 (2011)

5 N.R. Smart, D.J. Blackwood, L. Werme, Corrosion 58, 547 (2002)

6 N.R. Smart, D.J. Blackwood, L. Werme, Corrosion 58, 627 (2002)

7 N.R. Smart, D.J. Blackwood, G.P. Marsh, C.C. Naish, T.M. O’Brien, A.P. Rance, M.I. Thomas, The Anaerobic Corrosion of Carbon and Stainless Steels in Simulated Cementitious Repository Environments: A Summary Review of Nirex Research, AEAT/ERRA-0313, available from U.K. Nuclear Decommissioning Authority, (2004)

8 N.R. Smart, A.P. Rance and L.O. Werme, J. Nuc. Mat. 379, 97 (2008)

9 G. Schikorr, Z. Anorg. Chem 212, 33 (1933)

10 R. Grauer, The Corrosion Behaviour of Carbon Steel in Portland Cement, NAGRA Technical Report 88-02E, (1988) 
11 R. Grauer, B. Knecht, P. Kreis and J.P. Simpson, Werkstoffe und Korrosion 42, 637 (1991)

12 R. Grauer, B. Knecht, P. Kreis and J.P. Simpson, Mat. Res. Soc. Symp. Proc. 212, 295 (1991)

13 P. Kreis, Wasserstoffentwicklung durch Korrosion von Eisen und Stahl in anaeroben, alkalischen Medien im Hinblick auf ein SMA-Endlager, NAGRA Technical Report NAGRA-NTB-93-27, (1993)

14 R. Fujisawa, T. Cho, K. Sugahara, Y. Takizawa, Y. Horikawa, T. Shiomi and M. Hironaga, Mat. Res. Soc. Symp. Proc. 465, 675 (1997)

15 R. Fujiwara, I. Yasutomi, K. Fukudome, T. Tateishi and K. Fujiwara, Mat. Res. Soc. Symp. Proc. 663, 497 (2001)

16 M. Mihara, T. Nishimura, R. Wada and A. Honda, Saikuru Kiko Giho 15, 91-101 (2002)

17 A. Saleh, O. Azizi, O. Rosas-Camacho, A. Al-Marzooqi, D.D. Macdonald, Corrosion Engineering Science and Technology 46, 104-110 (2011) 